\title{
The 2015 Capstone Design Survey: Observations from the Front Lines
}

\section{Dr. Susannah Howe, Smith College}

Susannah Howe, Ph.D. is the Design Clinic Director in the Picker Engineering Program at Smith College, where she coordinates and teaches the capstone engineering design course. Her current research focuses on innovations in engineering design education, particularly at the capstone level. She is invested in building the capstone design community; she is a leader in the biannual Capstone Design Conferences and the Capstone Design Hub initiative. She is also involved with efforts to foster design learning in middle school students and to support entrepreneurship at primarily undergraduate institutions. Her background is in civil engineering with a focus on structural materials. She holds a B.S.E. degree from Princeton, and M.Eng. and Ph.D. degrees from Cornell.

\section{Ms. Sophia L. Poulos, Smith College}

Sophia Poulos is a 2016 engineering graduate from Smith College. She is interested in structural engineering and has worked on earthquake engineering projects with NEES@UCLA. She is a research assistant on the CDHub 2.0 initiative and innovations in engineering design education at the capstone level. She is pursuing a masters degree in structural engineering at the University of California Davis.

\section{Ms. Laura Mae Rosenbauer, Smith College}

Laura Rosenbauer is a student in the Smith College Picker Engineering Program. Laura is currently working with Director of the Design Clinic, Susannah Howe; and 2016 Smith Engineering graduate, Sophia Poulos on innovations in engineering design education at the capstone level. 


\title{
The 2015 Capstone Design Survey: Observations from the Front Lines
}

\begin{abstract}
Capstone design courses offer engineering students a culminating design experience on an applied engineering project, but the structure, logistics, and implementation of capstone courses varies widely. The 2015 Capstone Design Survey, conducted in spring 2015, continued the decennial census of capstone design courses to catalog current practices, identify emerging trends, and provide historical comparison. The survey reprised many of the questions from its 1994 and 2005 predecessors, augmented with additional questions based on other capstone-related surveys, design education conference topics, and open-ended responses. The survey was completed by 522 respondents representing 256 institutions across the U.S., including a handful of programs in other countries. This paper focuses specifically on the qualitative responses from the 2015 Capstone Design Survey, including capstone instructors' first-hand experiences and implementation practices. These qualitative data serve as a candid window into capstone design practices through the experiences of those who coordinate it, raising issues and highlighting current practices in engineering capstone design education to guide further development in the field.
\end{abstract}

\section{Introduction}

Capstone design courses provide a major design experience for engineering students, usually during their final year of undergraduate study. Although these courses are common across engineering programs in the U.S., they vary substantially in the way they are implemented. The first nationwide survey of capstone courses was conducted in 1994 in an effort to better understand current practices at the time. ${ }^{1}$ This was followed in 2005 by another nationwide survey ${ }^{2}$ using many of the same questions to update the data and also to capture trends over time; the 2005 survey repeated many of the questions from 1994, plus some new quantitative and open-ended response questions. A 2009 survey $^{3}$ included many of the quantitative logistical questions from 1994 and 2005 for comparative purposes, but extended the survey to include faculty experiences and opinions about capstone design pedagogy. Additional surveys across multiple institutions and capstone programs have been conducted by a variety of researchers on topics such as teaching load and funding, ${ }^{4}$ content in capstone design courses, ${ }^{5}$ capstone design problem statements, ${ }^{6}$ and technical design reviews. ${ }^{7}$ Other researchers have focused their surveys on specific engineering disciplines. ${ }^{8,9}$

The 2015 capstone design survey marks the official continuation of the decennial data collection effort. The 2015 survey included most of the questions from 1994 and 2005 plus a number of new multiple choice and open-ended questions, informed by the other recent surveys. The results of these surveys collectively are an important step towards understanding, assessing, and ultimately improving engineering capstone design education.

This paper focuses specifically on the qualitative responses from the 2015 Capstone Design Survey, including capstone instructors' first-hand experiences and implementation practices. (Highlights of the quantitative data are presented in a separate paper, ${ }^{10}$ the comprehensive results that also include longitudinal and disciplinary comparisons are forthcoming.) Respondents provided personal insights regarding what they enjoy most about capstone design, challenges they face, and self-identified strengths in their approaches to teaching and coordinating capstone design. Respondents also commented on a number of logistical topics, including design prerequisites, balancing product versus process, finding and selecting projects, project deliverables, collaboration across institutions, coordinating multiple faculty, and managing funding. The qualitative data serve as a candid window into capstone design practices 
through the experiences of those who coordinate it, raising issues and highlighting current practices in engineering capstone design education to guide further development in the field.

\section{Data Collection and Analysis Methodology}

The 2015 capstone survey included eleven main sections with a combination of multiple choice, fill-inthe-blank, and open response questions related to capstone course logistics, pedagogy, finances, and external relations, among others. The collection of questions was informed heavily by the previous nationwide and focused surveys referenced above, as well as discussions at previous capstone design conferences.

The survey was implemented using SurveyMonkey and sent via email to the department chairs of all ABET-accredited engineering and engineering technology programs, the ASEE DEED (Design in Engineering Education Division) monthly newsletter, and the Capstone Design Community mailing list. Recipients were asked to take the survey themselves if they were in charge of capstone design and/or to forward it to their capstone design colleagues. The survey was officially open during the month of February 2015 and responses were accepted through mid-March. A total of 522 respondents, representing 464 distinct departments at 256 institutions, participated in the survey.

This paper focuses solely on the qualitative responses to the eleven open-ended questions at the end of the survey. Participants were asked to "please provide responses to as many of the following questions as you choose; all information is welcome!" The collected responses represent a rich and extensive set of qualitative data with 250-350 separate responses per question.

The approach used for analyzing the responses followed an open coding and integration methodology. ${ }^{11}$ For each question, at least two authors independently read all responses and identified recurring content themes. All three authors compared, clarified, and consolidated the two separate lists into a single list of content themes. Two authors then independently coded the responses for the given question using the consolidated content themes. After working independently, the authors compared their resulting coding, discussed any discrepancies, and determined a final coding for each response; in many cases, responses were coded to more than one content theme. Then all three authors collaborated to group the content themes into broader categories for reporting and discussion. This process was repeated separately for each question.

\section{Results and Discussion}

Table 1 lists the eleven open-ended questions at the end of the survey in the order in which they appeared to the respondents. The sections below discuss each of the questions in turn, including both qualitative and quantitative discussion of the broader categories and the more specific content themes. Selected representative quotes are included throughout, followed by the respondent ID number in parentheses. 
Table 1 - Open-Ended Questions in the 2015 Capstone Design Survey

\begin{tabular}{|c|l|}
\hline Q1 & What are some of the strengths of your approach to teaching/coordinating capstone design? \\
\hline Q2 & What do you enjoy most about being involved with capstone design? \\
\hline Q3 & What are your biggest challenges regarding capstone design? \\
\hline Q4 & What design courses do you require as prerequisites for capstone design? \\
\hline Q5 & How do you balance product versus process in your capstone design projects? \\
\hline Q6 & What strategies do you use for finding capstone design projects? \\
\hline Q7 & What criteria do you use for selecting/vetting capstone design projects? \\
\hline Q8 & What are the typical deliverables for your capstone design projects? \\
\hline Q9 & $\begin{array}{l}\text { If you have ever collaborated with another institution on a capstone design project, how did you } \\
\text { structure the collaboration? }\end{array}$ \\
\hline Q10 & $\begin{array}{l}\text { If you involve multiple faculty in your capstone design course, how do you structure and manage } \\
\text { their involvement? }\end{array}$ \\
\hline Q11 & How is funding coordinated and managed for your capstone design course? \\
\hline
\end{tabular}

\section{$\underline{3.1 \text { Teaching/Coordinating Strengths }}$}

Responses to the question "What are some of the strengths of your approach to teaching/coordinating capstone design?" separated into a dozen categories, as shown in Table 2. Note that the content themes in Table 2 (and all similar tables for subsequent questions) are listed in descending order of frequency.

Over a quarter of respondents $(n=98)$ referred to their relationships as one of their teaching/coordinating strengths. A majority of these responses $(n=58)$ were regarding industry involvement, participation, and networking:

Networking. As I tell the students, 'It is not what you know, but who you know.' Communications, both written and oral. Interaction with local engineers, and city, county, and state agencies. (R310)

Incorporation of experienced project guides, who are typically retired engineers from industry who have a background working with multidisciplinary teams. (R135)

Responses in the relationships category also mentioned mentoring, advising, and nurturing frequently, with comments such as the following: "Providing students with a supportive environment so their teams can explore the concepts of design and project management, while providing them general guidance so they have an immersive, safe, self-learning experience." (R479)

A significant number of respondents $(\mathrm{n}=95)$ also noted that simulating a professional setting was an important part of their capstone design program. Of those responses, over half $(\mathrm{n}=48)$ referred to simulating authentic practices: "Attempt to treat the design team as if they are graduates employed by my firm." (R79) 
A similar number of respondents $(\mathrm{n}=47)$ addressed real-world projects, clients, and applications: "I attempt to use the capstone design project to illustrate a microcosm of the real world, giving students as close an experience to what they will encounter in design assignments." (R53)

Table 2 - Categories and Content Themes Regarding Teaching/Coordinating Strengths in Capstone Design

\begin{tabular}{|c|c|c|}
\hline Category & $\begin{array}{l}\text { \# Resp. } \\
(\mathrm{n}=\mathbf{3 6 1})\end{array}$ & $\begin{array}{l}\text { Content Themes } \\
\text { (in descending order of frequency) }\end{array}$ \\
\hline Relationships & 98 & $\begin{array}{l}\text { industry involvement; mentoring/advising/nurturing students; faculty } \\
\text { involvement; sustaining relationships with regional employers/advisory } \\
\text { board/alumni; close student-teacher interaction; transparency with students }\end{array}$ \\
\hline $\begin{array}{l}\text { Professional } \\
\text { Setting }\end{array}$ & 95 & $\begin{array}{l}\text { simulate authentic practice; real-world projects; interim reports, meetings; } \\
\text { keeping up with new and emerging technologies }\end{array}$ \\
\hline $\begin{array}{l}\text { Experience } \\
\text { Objectives }\end{array}$ & 80 & $\begin{array}{l}\text { oral and written communications skills; hands-on learning; student } \\
\text { professional development; opportunities for creativity and innovation; } \\
\text { application of concepts learned in class; emphasis on justifying decisions; } \\
\text { entrepreneurship; analysis and optimization; risk mitigation; open- } \\
\text { endedness; sustainability; life-cycle costing; balancing challenge and fun; } \\
\text { balancing process and results }\end{array}$ \\
\hline Resources & 71 & $\begin{array}{l}\text { faculty experience in industry; faculty experience in research; adequate } \\
\text { facilities; institutional support; location in major metropolitan area }\end{array}$ \\
\hline Investment & 50 & $\begin{array}{l}\text { student accountability; student engagement; connection to project; } \\
\text { commitment }\end{array}$ \\
\hline $\begin{array}{l}\text { Course } \\
\text { Framework }\end{array}$ & 39 & $\begin{array}{l}\text { multidisciplinary; systems engineering approach; flexible; two semester } \\
\text { duration; prerequisite curriculum; supportive environment to fail safely }\end{array}$ \\
\hline Design & 39 & $\begin{array}{l}\text { iteration and design process; design reviews; emphasis on conceptual design; } \\
\text { design heritage }\end{array}$ \\
\hline Teamwork & 38 & teamwork skills; team formation; team teaching; competition between teams \\
\hline $\begin{array}{l}\text { Organization/ } \\
\text { Logistics }\end{array}$ & 35 & project management; organization; marketing and promotion \\
\hline Project Scope & 25 & $\begin{array}{l}\text { emphasis on project framing at beginning; breadth of knowledge and variety } \\
\text { of topics; project phases build on previous }\end{array}$ \\
\hline Evaluations & 19 & $\begin{array}{l}\text { grading rubric; high expectations of students; external evaluation; integrating } \\
\text { ABET assessment }\end{array}$ \\
\hline $\begin{array}{l}\text { Integration/ } \\
\text { Connection }\end{array}$ & 12 & $\begin{array}{l}\text { integration of research/teaching/practice; connections made within and } \\
\text { outside of engineering }\end{array}$ \\
\hline
\end{tabular}

Experience objectives were referenced in a significant portion $(n=80)$ of responses as well. This category was split into fourteen subdivisions, but oral and written communication were emphasized the most $(\mathrm{n}=23)$ within the overall category, followed by hands-on learning/prototyping $(\mathrm{n}=22)$ and student professional development ( $\mathrm{n}=14)$, as illustrated in the selected comments below:

I take a practical approach, adding in how to build a team, how to justify a project, how to communicate with industry sponsors, and how to give an effective presentation. These topics give a more complete project once the analysis and design have been completed. (R122) 
We are very hands-on project oriented. Students start building prototypes and learning from their prototypes early. (R430)

Foster a culture of professionalism. Emphasis on having the students work with the customer to develop an appropriate spec, set of deliverables. Oversight provided, but project belongs to the students. (R361)

Throughout the entire group of responses, resources were also addressed fairly often $(n=71)$. Of those, a vast majority of the responses specifically referenced the faculty's experience in industry: "Relevant industry experience in Design helps relate the product development process to 'real life' and help the students envision their projects as more than an academic exercise." (R270)

\subsection{Enjoyment from Capstone Design}

Responses to the question "What do you enjoy most about being involved with capstone design?" clustered into eleven categories as shown in Table 3.

Table 3 - Categories and Content Themes Regarding Enjoyment from Capstone Design

\begin{tabular}{|c|c|c|}
\hline Category & $\begin{array}{l}\text { \# Resp. } \\
(\mathrm{n}=\mathbf{3 6 1})\end{array}$ & $\begin{array}{l}\text { Content Themes } \\
\text { (in descending order of frequency) }\end{array}$ \\
\hline $\begin{array}{l}\text { Personal } \\
\text { Success }\end{array}$ & 117 & $\begin{array}{l}\text { student success and accomplishment; student growth and confidence; } \\
\text { application of previous learning and skills; student joy and excitement; } \\
\text { student pride and self-recognition of achievements; "aha" moments; student } \\
\text { presentations; learning from failures; student risk-taking }\end{array}$ \\
\hline Interaction & 110 & $\begin{array}{l}\text { working with students; interacting with industry clients and sponsors; faculty } \\
\text { learning from students; collaborating with other faculty/departments/schools; } \\
\text { interacting with community }\end{array}$ \\
\hline $\begin{array}{l}\text { Professional } \\
\text { Development }\end{array}$ & 61 & $\begin{array}{l}\text { transformation from students to professionals; student motivation and } \\
\text { ownership; professional development and applications; teamwork } \\
\text { experiences; broad topics beyond just technical skills }\end{array}$ \\
\hline Variety & 52 & $\begin{array}{l}\text { variety and variability of projects; new ideas and perspectives; variety of } \\
\text { topics and skills }\end{array}$ \\
\hline Process & 48 & $\begin{array}{l}\text { design process; progression of projects; open-ended problem solving; } \\
\text { building and testing prototypes, hands-on experience }\end{array}$ \\
\hline Advising & 46 & $\begin{array}{l}\text { advising/coaching/mentoring/guiding students; sharing personal experiences } \\
\text { and expertise; student/teacher relationship }\end{array}$ \\
\hline Real World & 42 & $\begin{array}{l}\text { applied and relevant projects and problems; societal impact and value of } \\
\text { projects; staying current with new techniques and technologies; connection } \\
\text { between academia (theory) and industry (practice) }\end{array}$ \\
\hline Creativity & 36 & creativity/brainstorming/innovation; interesting problems \\
\hline $\begin{array}{l}\text { Project } \\
\text { Success }\end{array}$ & 30 & $\begin{array}{l}\text { overcoming tough and complex problems; providing good final result; } \\
\text { sponsor satisfaction }\end{array}$ \\
\hline Uniqueness & 10 & $\begin{array}{l}\text { not a standard course; designing the overall experience; proposing and } \\
\text { selecting projects; being part of tradition }\end{array}$ \\
\hline Extreme & 5 & all of it; do not enjoy \\
\hline
\end{tabular}


Nearly a third of the responses $(\mathrm{n}=117)$ addressed some aspect of personal success. Of those, the most common responses $(n=34)$ were related to student success and accomplishment:

Seeing the student succeed and overcome their struggles during the semester. Coming together as a team to produce real, quality project work. (R90)

Seeing the students tackle projects that initially seem much too large for them, and having them make substantial progress. (R250)

Nearly the same number of respondents $(\mathrm{n}=33)$ focused on student growth and confidence with comments such as "Seeing students mature in confidence." (R209) and "Seeing student growth over the two semesters - they really take ownership of their projects and their learning." (R433)

Other responses ( $\mathrm{n}=26)$ addressed the application of student learning: "Seeing the students apply the things they've learned throughout their time at the university." (R314) and "Students become excited as they apply their knowledge to solving actual problems." (R488) The next largest set of responses ( $\mathrm{n}=17)$ related to student joy and excitement with comments such as "The positive energy in the class is contagious." (R251)

Another large category of responses related to interactions of various sorts, including, most prominently, interactions with students $(n=75)$ and interactions with industry $(n=25)$ :

I find the interactions with the students to be very rewarding. (R163)

Working closely with students in small groups. (R448)

I enjoy the variety of the projects and the organizations that I work with. It interests me to be aware of the issues/problems our sponsors face. (R462)

Additional responses from some of the other categories in Table 3 related to enjoyment in capstone design are included below:

Not a standard lecture course. (R89)

New challenges for new projects with fresh ideas from new sets of students. (R266)

Seeing the team members evolve from students to novice engineers in their final year of coursework. (R334)

The opportunity to mentor students. I love helping them find great answers to challenging problems. (R68)

\subsection{Challenges in Capstone Design}

Responses to the question "What are your biggest challenges regarding capstone design?" grouped into fourteen categories as shown in Table 4. The three most common categories are discussed following Table 4. 
Table 4 - Categories and Content Themes Regarding Challenges in Capstone Design

\begin{tabular}{|c|c|c|}
\hline Category & $\begin{array}{l}\text { \# Resp. } \\
(\mathrm{n}=\mathbf{3 6 4})\end{array}$ & $\begin{array}{l}\text { Content Themes } \\
\text { (in descending order of frequency) }\end{array}$ \\
\hline $\begin{array}{l}\text { Workload/ } \\
\text { Time }\end{array}$ & 111 & $\begin{array}{l}\text { time in general; increasing class size; instructor time needed; other student } \\
\text { commitments; workload; time spent reading, writing, editing; prototype } \\
\text { fabrication and testing }\end{array}$ \\
\hline $\begin{array}{l}\text { Project- } \\
\text { related }\end{array}$ & 92 & $\begin{array}{l}\text { finding appropriate projects for the given time frame; financial support; finding } \\
\text { enough projects for the given time frame; equity across projects and faculty; } \\
\text { service learning projects; getting internal project data }\end{array}$ \\
\hline $\begin{array}{c}\text { Student } \\
\text { Involvement }\end{array}$ & 83 & $\begin{array}{l}\text { getting and maintaining student commitment; helping students start and } \\
\text { manage projects; student discomfort with open-ended problems; students who } \\
\text { are unmotivated; encouraging student independence and ownership; getting } \\
\text { students outside of their comfort zone; students going beyond the scope of the } \\
\text { project; getting students to justify and quantify design decisions }\end{array}$ \\
\hline No Support & 42 & $\begin{array}{l}\text { missing institutional support in value of capstone design courses; equipment } \\
\text { and facilities; having to "sell" the importance of the course; need staff and } \\
\text { admin support; institutional red tape }\end{array}$ \\
\hline $\begin{array}{l}\text { Student } \\
\text { Teams }\end{array}$ & 42 & $\begin{array}{l}\text { keeping healthy team dynamics and student teamwork; underperforming } \\
\text { students and teams; uneven effort within teams; assigning and balancing teams; } \\
\text { value of non-technical skills are just as important as the engineering; } \\
\text { perception of design as "soft engineering" }\end{array}$ \\
\hline $\begin{array}{c}\text { Faculty } \\
\text { Involvement }\end{array}$ & 26 & $\begin{array}{l}\text { faculty engagement; faculty without industrial experience; constraining faculty } \\
\text { to mentor and not to do the project; staying in the loop without being nosy }\end{array}$ \\
\hline $\begin{array}{c}\text { Student } \\
\text { Preparation }\end{array}$ & 23 & $\begin{array}{l}\text { understanding wide range of student preparation; student skills lack range of } \\
\text { experience; encouraging application of previous knowledge and skills; student } \\
\text { confidence }\end{array}$ \\
\hline $\begin{array}{l}\text { Industry } \\
\text { Involvement }\end{array}$ & 21 & $\begin{array}{l}\text { finding industry mentors or sponsors; personnel and organizational changes } \\
\text { and challenges in industry; sponsor distance }\end{array}$ \\
\hline $\begin{array}{l}\text { Meeting } \\
\text { Expectations }\end{array}$ & 20 & $\begin{array}{l}\text { ensuring high quality deliverable and student success; balancing expectations; } \\
\text { ensuring all team members learn as much as their potential allows, educational } \\
\text { benefit for all; ensuring students are ready for industry; accomplishment with } \\
\text { high stakes }\end{array}$ \\
\hline Evaluation & 17 & $\begin{array}{l}\text { evaluation (time and/or process); teaching evaluations; ABET assessment and } \\
\text { requirements }\end{array}$ \\
\hline $\begin{array}{l}\text { Variety/ } \\
\text { Breadth }\end{array}$ & 17 & $\begin{array}{l}\text { mentoring many different disciplines; need for diverse set of projects given } \\
\text { student interests; keeping current in the field(s); variety from year to year; } \\
\text { translating design terminology and language across disciplines; incorporating } \\
\text { entrepreneurship; }\end{array}$ \\
\hline $\begin{array}{l}\text { Course } \\
\text { Logistics }\end{array}$ & 16 & $\begin{array}{l}\text { overall coordination with other departments, schools, institutions; } \\
\text { continuous improvement }\end{array}$ \\
\hline Real World & 9 & $\begin{array}{l}\text { distinguishing between real world and theoretical applications; real world } \\
\text { obstacles that limit depth of work; leaving the classroom structure and not } \\
\text { letting it limit their design potential }\end{array}$ \\
\hline Misc. & 8 & no challenges; design work with students; export control \\
\hline
\end{tabular}


More than one third of the respondents $(\mathrm{n}=111)$ addressed challenges relating to some aspect of workload and time. Of those, the most common responses $(n=43)$ were related to time in general:

The short amount of time involved and the time it takes to complete a project. (R138)

Time intensive nature of advising individual projects for every student with no course. (R355)

Almost the same number of responses $(\mathrm{n}=41)$ focused on increasing class size, number of students, or number of projects: " $400+$ students, $70-80$ projects annually, 20 Faculty advisors, coordinated by 1 person." (R270) and "Dealing with a growing program without sacrificing our high-quality approach to teaching design." (R472)

Another large category of responses were project-related $(n=92)$, most prominently expressing challenges related to finding appropriate projects for the given time frame $(n=44)$ and financial support $(n=36)$ :

Finding projects that are appropriately challenging from sponsors that are willing to contribute financially. (R297)

Projects that have the right balance of difficulty and open-ended creativity for the student's level of expertise. (R249)

Finding the funding necessary to make the experience meaningful. (R362)

Multiple responses addressed the category of student involvement, such as getting and maintaining student commitment $(n=26)$, and helping students start and manage projects $(n=20)$ :

Motivating students to their full potential. (R460)

Keeping the students moving forward. They seem to be getting busier and busier with other classes as the years go by." (R335)

Keeping the teams 'on task'. The students are very curious and enjoy learning about the profession they are about to enter. (R94)

\section{$\underline{3.4 \text { Design Prerequisites }}$}

Responses to the question "What design courses do you require as prerequisites for capstone design?" grouped into nine categories, as shown in Table 5. 
Table 5 - Categories and Content Themes Regarding Design Prerequisites

\begin{tabular}{|c|c|c|}
\hline Category & $\begin{array}{l}\text { \# Resp. } \\
(\mathrm{n}=\mathbf{3 1 2})\end{array}$ & $\begin{array}{c}\text { Content Themes } \\
\text { (in descending order of frequency) }\end{array}$ \\
\hline $\begin{array}{l}\text { Specific } \\
\text { Courses }\end{array}$ & 132 & $\begin{array}{l}\text { specific elective courses and labs; department specific courses; sequence of } \\
\text { design courses; other design course(s) }\end{array}$ \\
\hline $\begin{array}{c}\text { Specific } \\
\text { Engineering } \\
\text { Topics }\end{array}$ & 91 & $\begin{array}{l}\text { machine design; design components in other courses; CAD; mechanical } \\
\text { design; thermal design; software engineering, software design; design and } \\
\text { manufacturing; simulation/testing; design theory, methods; experimental } \\
\text { methods; construction management; component design; system design; } \\
\text { modeling with architectural drawings; product design }\end{array}$ \\
\hline None & 61 & none/nothing specific \\
\hline Specific Years & 52 & $\begin{array}{l}\text { freshman design/intro to design; junior design; sophomore design; senior } \\
\text { design }\end{array}$ \\
\hline Criteria-Based & 31 & senior standing or minimum \# of credits \\
\hline Other Topics & 17 & $\begin{array}{l}\text { economics; project management; technical communications, technical } \\
\text { writing; math; physics }\end{array}$ \\
\hline Varies & 11 & varies by department/major \\
\hline Most/All & 11 & $\begin{array}{l}\text { most or all elective courses; all core courses through } 300 \text { level; all core } \\
\text { courses }\end{array}$ \\
\hline General Yes & 8 & (no themes - response affirms that there are design prerequisites) \\
\hline
\end{tabular}

The most common type of response regarding design prerequisites from participants $(n=132)$ was a list of specific courses. Of those answers, nearly half $(n=69)$ were specific elective courses or labs, with the remaining responses distributed fairly equally, as shown in Figure 1. Heat transfer, circuits, and fluids were some of the more popular examples of specific elective courses provided by respondents.

Specific elective courses and labs

Department specific courses

Sequence of design courses

Other design course(s)

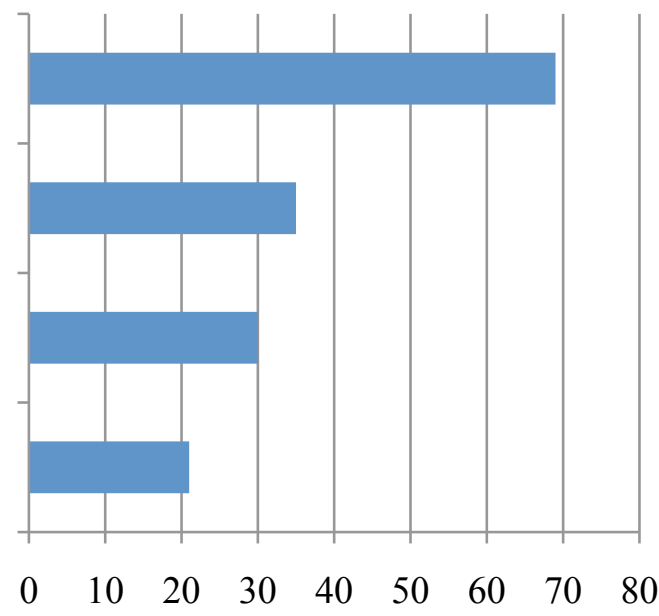

Number of Responses

Figure 1 - Distribution of Responses Regarding Specific Courses for Design Prerequisites in Capstone Design $(n=132)$ 
Specific engineering topics were listed as design prerequisites by nearly a third of respondents $(n=91)$, with machine design counting for a third of the responses $(n=30)$. This category has significant overlap with the content themes from the specific courses category; answers that listed course titles within the engineering department fell into both categories. However, it is important to make the distinction between responses simply providing general engineering topics, and those listing specific courses.

A large number of respondents $(n=61)$ also stated that there were no design prerequisites for their program. While some elaborated on why prerequisites were not necessary, or expressed a hope to implement requirements in the future, the most common answer in this category was simply "none."

\section{$\underline{3.5 \text { Product Versus Process }}$}

An oft-discussed topic in the biannual capstone design conferences is that of product versus process in capstone design. As such, the 2015 survey asked respondents "How do you balance product versus process in your capstone design projects?" Responses to the question included leaning toward process, leaning toward product, and an even balance, in addition to some other categories, as shown in Table 6 .

Table 6 - Categories and Content Themes Regarding Balance of Product and Process

\begin{tabular}{|c|c|l|}
\hline Category & $\begin{array}{c}\text { \# Resp. } \\
\text { (n=279) }\end{array}$ & \multicolumn{1}{c|}{$\begin{array}{c}\text { Content Themes } \\
\text { (in descending order of frequency) }\end{array}$} \\
\hline More Process & 106 & emphasis on process; heavy emphasis on process; all process \\
\hline Split & 82 & $\begin{array}{l}\text { equally - both important; lectures are process oriented, projects are product } \\
\text { oriented; process = faculty, product = students/sponsor; emphasis on process } \\
\text { early, on product later }\end{array}$ \\
\hline Variable & 33 & $\begin{array}{l}\text { varies (by project, by faculty mentor, by sponsor, by students); instructor's } \\
\text { discretion; discussion with students }\end{array}$ \\
\hline Other & 32 & $\begin{array}{l}\text { final product is important for final grade; product is process - no physical } \\
\text { product; other; good projects matter more than either }\end{array}$ \\
\hline More Product & 31 & emphasis on product; heavy emphasis on product; all product \\
\hline N/A, Not Well & 12 & N/A, not sure; not balanced, not done well \\
\hline Interdependent & 11 & $\begin{array}{l}\text { good process (usually) leads to good product; product is necessary but not } \\
\text { sufficient }\end{array}$ \\
\hline
\end{tabular}

Although there are capstone programs that focus on product, the majority of respondents either weigh the two equally or emphasize process, as illustrated by Figure 2. Responses were coded by specific content theme based on numerical value provided $(51-74 \%=$ "emphasis", $75-94 \%=$ "heavy emphasis", $95-100 \%$ $=$ "all") or interpretation of the response by the researchers based on wording and adjectives.

Representative responses are provided in Table 7.

Regardless of emphasis, multiple respondents $(\mathrm{n}=23)$ indicated that the final product is an important component of the final grade: "Both are important, but the project only succeeds if the students complete a working product." (R380) and "Process is more important but a physical working prototype is required." (R472) 


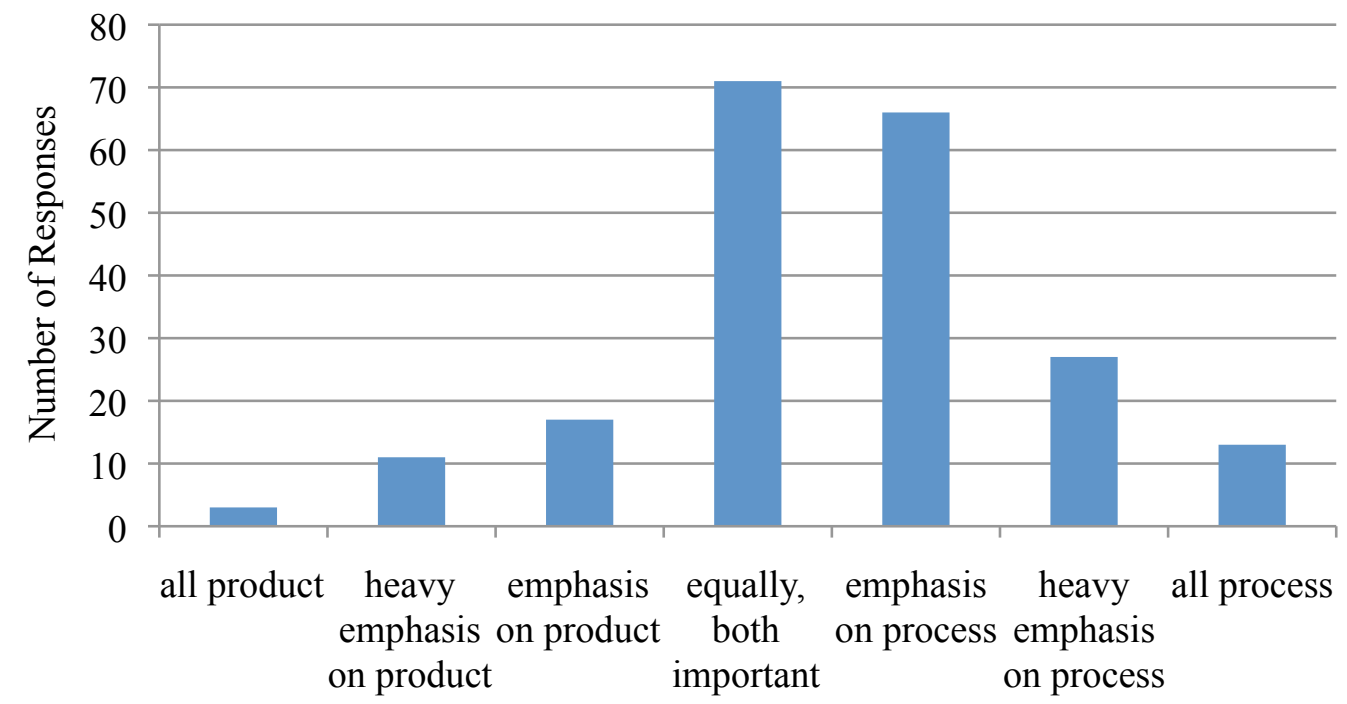

Figure 2 - Distribution of Responses along a Product-Process Spectrum

Table 7 - Representative Responses along a Product-Process Spectrum

\begin{tabular}{|l|l|}
\hline \multicolumn{1}{|c|}{ Content Theme } & \multicolumn{1}{c|}{ Representative Response (Respondent \#) } \\
\hline All Product & Product is key! (R41) \\
\hline $\begin{array}{l}\text { Heavy Emphasis on } \\
\text { Product }\end{array}$ & We focus most on the product and very little on processes. (R99) \\
\hline Emphasis on Product & $\begin{array}{l}\text { Probably 60\% on the product and } 40 \% \text { on the process, especially formal } \\
\text { processes. (R149) }\end{array}$ \\
\hline $\begin{array}{l}\text { Equally, Both } \\
\text { Important }\end{array}$ & We emphasize, evaluate and give time to both equally. (R454) \\
\hline Emphasis on Process & Process wins out, but product usually follows for a good process. (R294) \\
\hline $\begin{array}{l}\text { Heavy Emphasis on } \\
\text { Process }\end{array}$ & $\begin{array}{l}>80 \% \text { process which is consistent with the types of jobs available for and skills } \\
\text { expected for our graduating engineers. (R418) }\end{array}$ \\
\hline $\begin{array}{l}\text { All Process } \\
\text { We typically don't build the real products, as the system costs millions to } \\
\text { construct. Hence, we focus on the design process. (R100) }\end{array}$ \\
\hline
\end{tabular}

\section{$\underline{\text { 3.6 Finding Capstone Projects }}$}

Responses to the question "What strategies do you use for finding capstone design projects?" are clustered in nine categories, as shown in Table 8. The four most common categories are discussed following the table. 
Table 8 - Categories and Content Themes Regarding Finding Capstone Projects

\begin{tabular}{|c|c|l|}
\hline Category & $\begin{array}{c}\text { \# Resp. } \\
\text { (n=321) }\end{array}$ & \multicolumn{1}{c|}{$\begin{array}{c}\text { Content Themes } \\
\text { (in descending order of frequency) }\end{array}$} \\
\hline $\begin{array}{c}\text { External } \\
\text { Contacts }\end{array}$ & 173 & $\begin{array}{l}\text { local and regional industries; alumni; industrial advisory board; previous } \\
\text { sponsors; connections in general; personal contacts of capstone instructor; } \\
\text { faculty and department contacts; development office; word of mouth; student } \\
\text { contacts; co-op and internship contacts; clinicians; other university's } \\
\text { capstone project sponsors }\end{array}$ \\
\hline $\begin{array}{c}\text { Internal } \\
\text { Sources }\end{array}$ & 92 & $\begin{array}{l}\text { student-proposed; faculty research and ideas; brainstorming; on-campus } \\
\text { projects }\end{array}$ \\
\hline Marketing & 85 & solicitation and networking; advertising; internet searches \\
\hline Prefabricated & 28 & competitions; repeat previous projects; textbooks \\
\hline Criteria-based & 21 & global trends and industry needs; multidisciplinary groups \\
\hline Magnet & 16 & approached externally; reputation \\
\hline Who Finds & 14 & dedicated capstone personnel; leave to faculty mentor \\
\hline Extreme & 10 & no coordinate strategy; anything and everything \\
\hline Events-based & 7 & demo day or project day; attend career day; conferences \\
\hline
\end{tabular}

Over half of responses $(\mathrm{n}=173)$ utilized external contacts as a source of finding projects. Of those, about a third of respondents $(\mathrm{n}=50)$ mentioned local and regional industries: "Keep sponsors located within a 90 mile radius." (R71) and "Contact local clients/foundations/clinics/centers." (R389)

A comparable number of comments $(n=49)$ remarked that alumni were a significant source of projects:

Advisory board provides some, but most successful is former students. Best sponsors are those that have been out of school for 4-5 years. Senior-level sponsors of projects are often too busy to be responsive, and forget what students can do as seniors. (R154)

Our alumni network is our best resource. (R303)

Many responses ( $\mathrm{n}=92)$ also pointed out internal sources of projects, with student-proposed ideas making up a majority $(\mathrm{n}=58)$, followed by faculty research and ideas $(\mathrm{n}=50)$.

Student interests; students have to come up with projects for my approval. (R186)

Have the students go out and talk to people to identify a real problem and then solve it. (R414)

Faculty research, grants and other activity generate projects. (R376)

We sit around in a room a few times over the course of several weeks and bring in ideas that [are] of our interest. These may be of personal interest, from papers we have read, extensions of previous class problems, extensions of research. (R458)

Another category frequently addressed was marketing $(n=84)$, of which the most common theme by far was solicitation and networking $(n=69)$ : 


\section{Actively reaching out to industry and other potential sponsors and making sure they become}

aware of the value of their contribution. (R125)

Creative and proactive and aggressive with potential sponsors, jump on opportunities.

\subsection{Selecting/Vetting Capstone Projects}

Following up on the question about finding capstone projects, the 2015 survey also asked about what criteria respondents use to select/vet capstone design projects. The 311 responses to this question are grouped into ten main categories, as shown in Table 9; most comments mapped to more than one category and more than one content theme within a category, suggesting that respondents have multiple criteria for selecting/vetting projects.

Table 9 - Categories and Content Themes Regarding Selecting/Vetting Capstone Projects

\begin{tabular}{|c|c|l|}
\hline Category & $\begin{array}{c}\text { \# Resp. } \\
\text { (n=311) }\end{array}$ & \multicolumn{1}{c|}{$\begin{array}{c}\text { Content Themes } \\
\text { (in descending order of frequency) }\end{array}$} \\
\hline Good Fit & 155 & $\begin{array}{l}\text { appropriate scope and complexity for course duration and team size; } \\
\text { appropriate rigor and technical challenge given student abilities; matched to } \\
\text { curriculum and disciplines/departments involved; satisfies academic } \\
\text { requirements; suitable for available facilities and resources; incorporates } \\
\text { multiple disciplines, fairness across disciplines; geographic location, local } \\
\text { and accessible }\end{array}$ \\
\hline Who Chooses & 81 & $\begin{array}{l}\text { capstone instructor discretion and experience; faculty review; student } \\
\text { decision; technical merit matrix }\end{array}$ \\
\hline $\begin{array}{c}\text { Experience } \\
\text { Opportunities }\end{array}$ & 56 & $\begin{array}{l}\text { opportunity to build prototype; open-ended; enables student learning } \\
\text { experience; allows creativity and innovation }\end{array}$ \\
\hline $\begin{array}{c}\text { Baseline } \\
\text { Content }\end{array}$ & 49 & $\begin{array}{l}\text { includes design; includes engineering analysis; includes hardware and/or } \\
\text { software component; requires engineering and non-engineering knowledge }\end{array}$ \\
\hline $\begin{array}{c}\text { Baseline } \\
\text { Logistics }\end{array}$ & 49 & $\begin{array}{l}\text { sufficient funding; available data and background information; has clear } \\
\text { design requirements and goals; satisfies ABET; does not require research; } \\
\text { not illegal or unsafe; can be evaluated; students can own IP }\end{array}$ \\
\hline $\begin{array}{c}\text { Sponsor } \\
\text { Relations }\end{array}$ & 37 & $\begin{array}{l}\text { available and approachable sponsor liaisons; credibility of sponsor; track } \\
\text { record or previous collaboration with company; not on company critical path }\end{array}$ \\
\hline $\begin{array}{c}\text { Interesting } \\
\text { Real World }\end{array}$ & 36 & $\begin{array}{l}\text { of interest to students; of interest to faculty; connection to faculty research or } \\
\text { expertise; institutional visibility }\end{array}$ \\
\hline Success & 20 & $\begin{array}{l}\text { value to client - not contrived; societal impact; not already available } \\
\text { commercially; representative of current work in industry }\end{array}$ \\
\hline probability of success; doable \\
\hline None/Varies
\end{tabular}

About half the responses map to the category of "good fit", suggesting that ensuring a good fit between the project and various parameters of the capstone program was important to many respondents. Within this category, the majority of responses focused on appropriate scope and complexity for course duration 
and team size $(\mathrm{n}=94)$ and/or appropriate rigor and technical challenge given student abilities $(\mathrm{n}=48)$, as shown in the selected responses below:

Project must be of sufficient complexity, sufficient quantity of work for 3-5 people. (R64)

Is the project area large enough to allow development of several alternatives, but small enough to cover easily in a semester? (R383)

Is it appropriate for a team of senior engineering students to complete in nine months; it the project challenging enough or too challenging? (R203)

Some respondents within the good fit category $(\mathrm{n}=32)$ also focused on matching projects to their curriculum or the disciplines or departments involved: "Must include the major process activities, e.g., fluid flow, mass heat and mass transfer, etc." (R242)

Many respondents ( $\mathrm{n}=56)$ noted that they select projects to ensure opportunities for particular experiences such as prototyping, exploring multiple solutions, student learning, and creativity, with comments along the lines of "It must be able to have a prototype or critical sub component built by the students within the academic calendar." (R192) and "Possibility for multiple solutions for students to explore and decide between." (R24).

A set of responses centered around necessary baseline parameters for projects, either related to project content or project logistics. The vast majority of project content responses addressed the need for the project to include design ( $\mathrm{n}=37)$ : "They must have a design component as opposed to being an undergraduate research project." (R281) There were multiple themes within baseline project logistics, but the most common one was sufficient project funding $(\mathrm{n}=21)$, with comments such as "Project must be sufficiently funded for materials, equipment, and printing (no charges are made for salaries, wages, and overhead)." (R456)

In addition to specific criteria for selecting projects, about a quarter of respondents $(n=81)$ also provided information regarding who does the selecting, with most mapping to either instructor discretion $(\mathrm{n}=36)$ or faculty review $(n=36)$.

My experience and judgement as to their abilities and the degree of difficulty of the project. (R396)

Faculty review all available options and select projects of proper scope. Students then can choose from a pre-selected list. (R298)

\section{$\underline{3.8 \text { Typical Deliverables }}$}

Themes observed in responses to the question "What are the typical deliverables for your capstone design projects?" grouped into ten categories, as shown in Table 10. The three most common typical deliverables were written reports, product, and visual/oral presentations, which are discussed following Table 10 .

Of the 328 respondents, more than two thirds $(n=230)$ indicated written reports as being a typical deliverable. The most common types of written reports were a final report $(n=220)$ and interim reports $(\mathrm{n}=38)$, as shown in Figure 3. 
Table 10 - Categories and Content Themes Regarding Typical Deliverables

\begin{tabular}{|c|c|l|}
\hline Category & $\begin{array}{c}\text { \# Resp. } \\
\text { (n=328) }\end{array}$ & \multicolumn{1}{c|}{$\begin{array}{c}\text { Content Themes } \\
\text { (in descending order of frequency) }\end{array}$} \\
\hline Written Reports & 230 & $\begin{array}{l}\text { final report; interim reports; final recommendation; patent disclosure; } \\
\text { conference or journal paper }\end{array}$ \\
\hline Product & 201 & final prototype or working device; complete design package/portfolio \\
\hline $\begin{array}{c}\text { Visual/Oral } \\
\text { Presentations }\end{array}$ & 159 & final presentation; poster; interim presentations; infographic; elevator pitch \\
\hline $\begin{array}{c}\text { Evidence of } \\
\text { Design Process }\end{array}$ & 79 & $\begin{array}{l}\text { design process documentation; design specifications; project notebook or } \\
\text { logbook; design reviews; design history file or record }\end{array}$ \\
\hline $\begin{array}{c}\text { Design } \\
\text { Justification }\end{array}$ & 49 & verification and validation; economic evaluation \\
\hline Multimedia & 35 & software; video; website; CD/DVD/USB of project files \\
\hline Status Updates & 35 & regular progress/status reports; schedules \\
\hline $\begin{array}{c}\text { Plan/Manual } \\
\text { General }\end{array}$ & 29 & user manual or training manual; business plan; manufacturing plan \\
\hline $\begin{array}{c}\text { Student } \\
\text { Accountability }\end{array}$ & 16 & varies; client determined deliverables; many deliverables; the usual \\
\hline
\end{tabular}

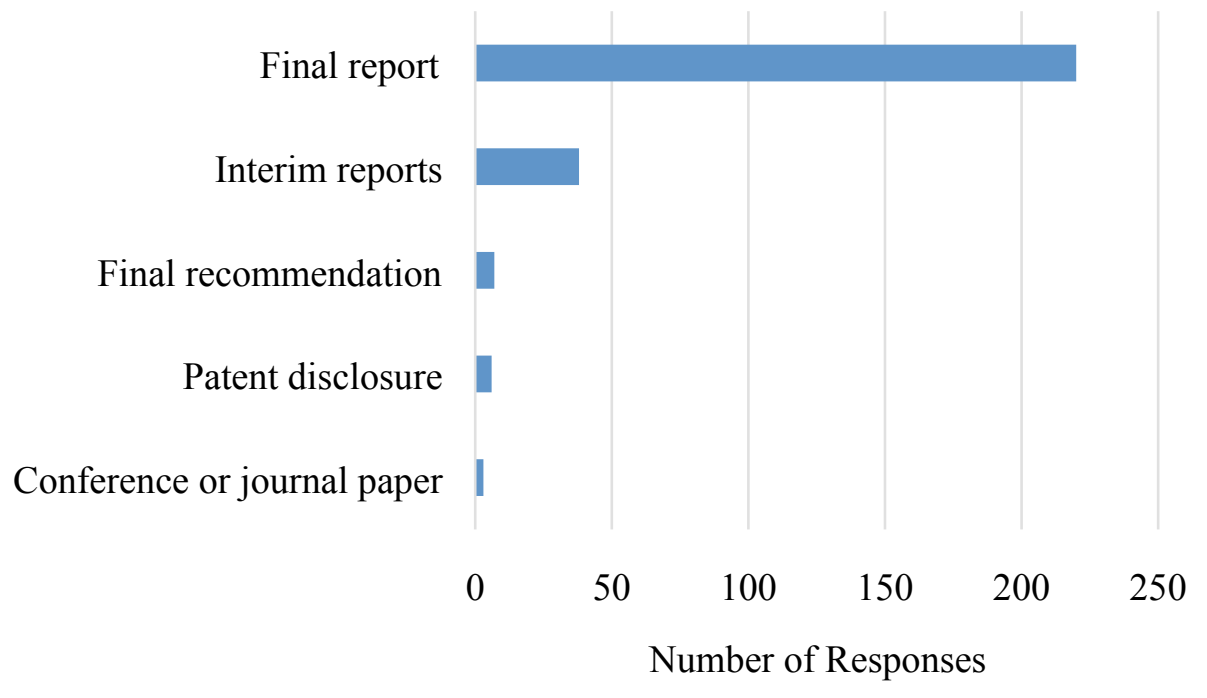

Figure 3 - Distribution of Types of Written Reports as Typical Deliverables ( $\mathrm{n}=230$ )

Many respondents indicated a product $(\mathrm{n}=201)$ as their typical deliverable. Of those responses, $89 \%$ were a final prototype or working device and $16 \%$ required a product in the form of a complete design package/portfolio. (The overlapping 5\% required both.) Another common type of deliverable was visual/oral presentations $(n=159)$. Within this category, final presentation $(n=142)$ was required by the largest number of respondents, followed by a poster $(n=41)$, as shown in Figure 4 . 


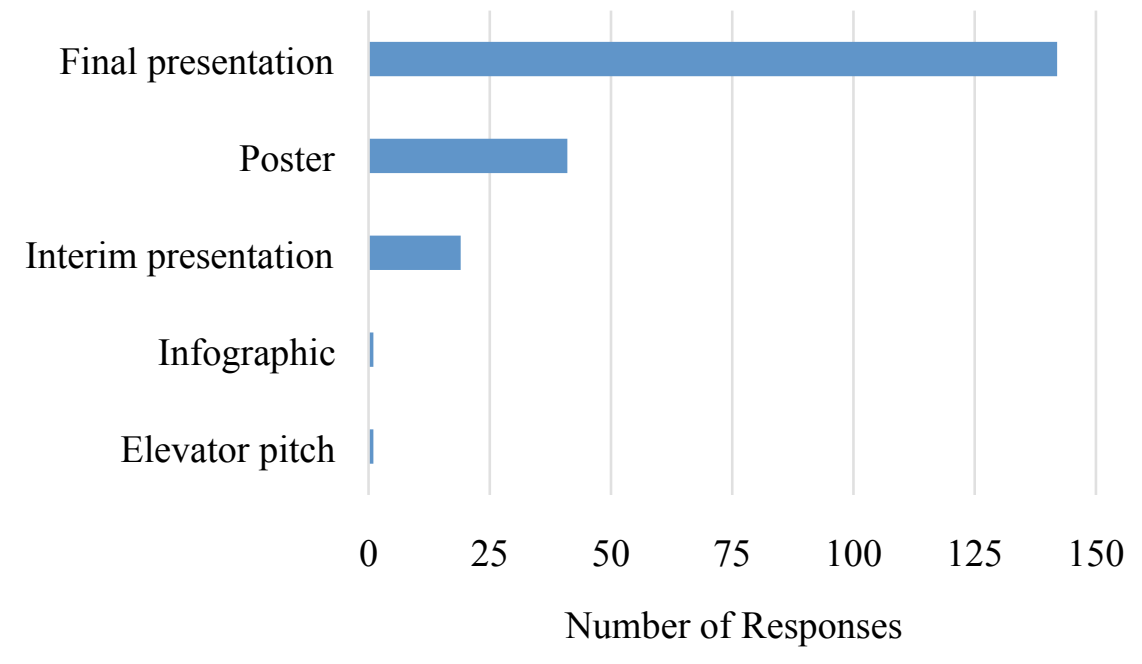

Figure 4 - Distribution of Types of Visual/Oral Presentations ( $\mathrm{n}=159)$

\subsection{Collaboration Across Institutions}

Two hundred respondents provided some response to the question "If you have ever collaborated with another institution on a capstone design project, how did you structure the collaboration?" but 136 of those responses indicated that the question was not applicable $(n=122)$ or that the respondent had never done such a collaboration, had done one only in the distant past, or were planning one for the future. The remaining 67 responses could be grouped into eight categories, each with its own content themes, as shown in Table 11.

Table 11 - Categories and Content Themes Regarding Collaboration across Institutions

\begin{tabular}{|c|c|c|}
\hline Category & $\begin{array}{c}\text { \# Resp. } \\
(n=67)\end{array}$ & $\begin{array}{c}\text { Content Themes } \\
\text { (in descending order of frequency) }\end{array}$ \\
\hline $\begin{array}{l}\text { Logistics and } \\
\text { Strategies }\end{array}$ & 31 & $\begin{array}{l}\text { regular communication; interim deadlines; students graded by faculty at } \\
\text { home institution; faculty advisors at both institutions handle coordination; } \\
\text { faculty member mentors team of students from both institutions; collaborator } \\
\text { as source of projects; one institution follows schedule of other; team involves } \\
\text { one student from a different institution; establish written requirements in } \\
\text { advance; students responsible for deliverables at home institution; work } \\
\text { together to make a schedule }\end{array}$ \\
\hline Split Work & 13 & $\begin{array}{l}\text { split project by type of work or discipline; informal idea exchange; work } \\
\text { independently but share information; subcontract portions of design; each } \\
\text { institution responsible for separate part with communication at the interfaces }\end{array}$ \\
\hline Shared Work & 6 & collaborate on common project as equal partners; share datasets \\
\hline $\begin{array}{c}\text { Other } \\
\text { Collaboration }\end{array}$ & 6 & $\begin{array}{l}\text { collaborate across departments but not institutions; collaborate with K-12 } \\
\text { institutions }\end{array}$ \\
\hline Varies & 6 & varies by project and collaboration \\
\hline General Yes & 8 & (no themes - affirmative response confirms that collaboration exists) \\
\hline Failed & 3 & did not work \\
\hline
\end{tabular}


Most content themes had only a few responses and none had more than ten. A sampling of responses from some of the most frequently mentioned content themes is provided below:

We communicated using six channels including e-mail, blog, Google Docs, Adobe web conference, social networking system (SNS), and cloud computing. We arranged regular meetings and communicated steadily, using these channels to share ideas and developments in the project. (R188)

Worked with the local community college. Our students designed the mechanical systems, their tech students designed the electrical components. (R498)

Structure is developed on a case by case basis with each institution that depends on institutional policies and partnerships. (R481)

\subsection{Involving Multiple Faculty}

Involving multiple faculty was much more common than involving multiple institutions. The responses to the question "If you involve multiple faculty in your capstone design course, how do you structure and manage their involvement?" were grouped into ten main categories and associated content themes, as shown in Table 12. It is worth noting that although 253 respondents answered the question, 42 of these respondents indicated that the question was either not applicable or that their capstone program was run by only a single faculty member.

The largest number of responses mapped to the "shared responsibility" category. Within this, the most common responses $(n=38)$ indicated some form of tiered system with one primary course instructor who manages the course and oversees other faculty who mentor teams, with comments such as the following:

Lead instructor manages a teaching team comprising other faculty, academic coordinator, staff engineers and teaching assistants. (R57)

One faculty is the main coordinator and others just mentor teams. (R21)

Nearly as many responses $(n=36)$ within the "shared responsibility" category noted that multiple faculty share the responsibilities more evenly:

We have 3 faculty in our capstone; each has equal responsibility for course structure, decision, and grading. We also divide the total number to teams between the 3 faculty equally, such that each faculty member serves as a mentor to about 4 teams. Each faculty member shares in the lecture and grading duties. (R398)

We work together, agree on deliverables, and in general model the teamwork we expect from our students. (R77)

Many responses to the question of multiple faculty involvement had to do with faculty/team interactions. The vast majority of these responses $(\mathrm{n}=59)$ noted that faculty were involved as advisors, mentors, and coaches: "Multiple faculty are engaged as project advisors." (R201) 
Table 12 - Categories and Content Themes Regarding Involving Multiple Faculty

\begin{tabular}{|c|c|c|}
\hline Category & $\begin{array}{l}\text { \# Resp. } \\
(\mathrm{n}=\mathbf{2 5 3})\end{array}$ & $\begin{array}{c}\text { Content Themes } \\
\text { (in descending order of frequency) }\end{array}$ \\
\hline $\begin{array}{c}\text { Shared } \\
\text { Responsibility }\end{array}$ & 86 & $\begin{array}{l}\text { tiered system; multiple faculty share responsibilities; multiple faculty } \\
\text { inform grading; involve graduate students as TAs; involve all faculty }\end{array}$ \\
\hline $\begin{array}{l}\text { Faculty/Team } \\
\text { Interaction }\end{array}$ & 76 & $\begin{array}{l}\text { faculty as advisors/mentors/coaches; faculty matched to teams by expertise; } \\
\text { faculty as customer or client; faculty as team manager; one team per faculty } \\
\text { member; multiple teams per faculty member }\end{array}$ \\
\hline NA/Not Well & 57 & $\begin{array}{l}\text { not applicable; one faculty member for whole course; no formal structure; } \\
\text { not well managed; want more faculty involvement }\end{array}$ \\
\hline $\begin{array}{l}\text { Minor } \\
\text { Involvement }\end{array}$ & 46 & $\begin{array}{l}\text { faculty review final presentations and/or final product; faculty as technical } \\
\text { consultants; faculty as occasional guest speakers; faculty serve as needed; } \\
\text { faculty review portion of project connected to their expertise; faculty } \\
\text { volunteer if they have interest }\end{array}$ \\
\hline Divided Roles & 27 & $\begin{array}{l}\text { divide by discipline/topic/interest; establish clear roles and responsibilities; } \\
\text { divide by parts (lecture/lab, or lecture/project); divide chronologically; } \\
\text { faculty teach separate sections; multiple faculty with no collaboration }\end{array}$ \\
\hline Communication & 23 & $\begin{array}{l}\text { regular meetings between faculty and students; personal communication } \\
\text { between faculty; faculty meet with each other across different departments }\end{array}$ \\
\hline Variable & 16 & varies from year to year depending on faculty; arranged by faculty involved \\
\hline Student-Driven & 13 & $\begin{array}{l}\text { students seek faculty for technical expertise; students request faculty mentor } \\
\text { for project; involve student leadership team }\end{array}$ \\
\hline General Yes & 11 & (no themes - response affirms only that multiple faculty are involved) \\
\hline $\begin{array}{l}\text { Teaching } \\
\text { Credit }\end{array}$ & 5 & $\begin{array}{l}\text { teaching credits assigned based on number of teams mentored; no teaching } \\
\text { credit granted; use formula to determine number of instructors needed }\end{array}$ \\
\hline
\end{tabular}

Another popular category focused on many ways that multiple faculty could be involved in a minor way. The most common approach noted in these responses $(\mathrm{n}=17)$ was faculty involvement in reviewing final presentations or deliverables: "Other faculty serve as team mentors, as well as helping out in the grading of the design reviews and final presentations." (R150) Another approach mentioned by 12 respondents was to involve faculty as technical consultants: "All of our faculty are expected to act as technical consultants within their area of expertise for the senior design teams." (R241) In addition, 10 respondents mentioned guest lecturing as a way they involve multiple faculty: "Other faculty sometimes participate as guest speakers on a relevant technical topic." (R509)

\subsection{Coordinating and Managing Funding}

The quantitative portion of the survey included several questions about levels and sources of funding for capstone design; the summary of these data are presented elsewhere. ${ }^{10}$ The open-ended portion of the survey asked respondents about how funding is coordinated and managed. Themes found in the given responses were grouped into five categories, as shown in Table 13. The categories of management and allocation, though similar, are distinct in that allocation refers to the methods by which funds are handled or dispensed, and management refers to who is in charge of doing so. 
Table 13 - Categories and Primary Content Themes Regarding Coordinating and Managing Funding

\begin{tabular}{|c|c|l|}
\hline Category & $\begin{array}{c}\text { \# Resp. } \\
\text { (n=262) }\end{array}$ & \multicolumn{1}{c|}{$\begin{array}{c}\text { Content Themes } \\
\text { (in descending order of frequency) }\end{array}$} \\
\hline Management & 115 & $\begin{array}{l}\text { managed by department; managed by faculty or instructor; managed by } \\
\text { capstone program; managed by student or team; managed externally; sponsor } \\
\text { fee recorded as gift or grant; management varies; managed by sponsor; } \\
\text { grades not assigned until budget is reconciled }\end{array}$ \\
\hline N/A, Not Well & 106 & no funding; not well or with difficulty; varies; don't know \\
\hline $\begin{array}{c}\text { Funding } \\
\text { Source }\end{array}$ & 105 & $\begin{array}{l}\text { funded by sponsor or client; funded by department or course budget; funded } \\
\text { by course or lab fee; funded by external donations; funded by specific grant; } \\
\text { funded by students out of pocket; funded by dean or institution; funding } \\
\text { varies }\end{array}$ \\
\hline Allocation & 21 & $\begin{array}{l}\text { allotted via one central account; allotted by reimbursement; allotted per } \\
\text { project basis; for specific project expense; allotted via prepaid debit or gift } \\
\text { card; allocation varies }\end{array}$ \\
\hline Amount & 17 & $\begin{array}{l}\text { amount is set per student or team; amount can be petitioned by teams for } \\
\text { more; amount set by department chair }\end{array}$ \\
\hline
\end{tabular}

Nearly half of the total responses $(n=115)$ addressed management; of these, responses that indicated management by the department $(n=51)$ or by faculty/instructors $(n=40)$ were the vast majority.

Following closely behind management, a variety of responses commented on the institution's lack of organization, or lack of funds in general $(n=106)$. While some of these respondents expressed a hope for better coordination in the future, others appeared to find it unnecessary.

It is not. I would like to establish a source of funding for the course. As of now, it is addressed on an ad hoc basis. (R462)

This has been a struggle, we are still figuring this out. (R219)

Not an issue: Chemical engineering capstone process design is entirely virtual. (R222)

Although the question only inquired about coordinating and managing funding, many respondents $(\mathrm{n}=105)$ described funding sources in addition to or in place of management practices. Of these, a large group $(n=47)$ reported sponsors or clients as their source of funding. A similar number of respondents $(\mathrm{n}=38)$ listed their department or course budget.

\section{Conclusions and Future Work}

The 2015 Capstone Design Survey, conducted in spring 2015, continued the decennial census of capstone design courses to catalog current practices, identify emerging trends, and provide historical comparison. The survey reprised many of the questions from its 1994 and 2005 predecessors, augmented with additional questions based on other capstone-related surveys, design education conference topics, and open-ended responses. This paper focuses specifically on the qualitative responses from the 2015 Capstone Design Survey, including capstone instructors' first-hand experiences and implementation practices. The data were analyzed using an open-coding approach to identify specific content themes. 
The breadth of themes that emerged from the responses for each question underscores the variety of logistical and pedagogical practices utilized in different capstone design programs, far beyond what could easily be captured in a pre-defined multiple choice survey question. The most commonly mentioned themes and overarching categories are a useful indicator of what is "standard" practice in capstone design education; they also serve as a possible starting place for determining what are "effective" practices.

The qualitative data in this paper complement the quantitative responses highlighted in a 2016 Capstone Design Conference paper. ${ }^{10}$ A longer paper including these quantitative and qualitative results, plus longitudinal and disciplinary comparisons, is in process for IJEE. In addition, the 2015 survey has already been distributed to capstone programs in Australia and New Zealand; plans are underway to collect data from other countries as well.

\section{Acknowledgements}

The authors offer thanks to the survey respondents for taking the time to share their program logistics and personal experiences in the 2015 survey. The authors acknowledge Natasha Culbreth and Iris Umaña for assistance in the 2015 survey creation and distribution, and the other researchers who have conducted related surveys and shared their results with the broader engineering education community.

Bibliography:

1. Todd, R.H., et al. "A Survey of Capstone Engineering Courses in North America," Journal of Engineering Education, 1995. 84(2): pp. 165-174.

2. Howe, S. "Where Are We Now: Statistics on Capstone Courses Nationwide," Advances in Engineering Education, 2010. 2(1): pp. 1-27.

3. Pembridge, J. and Paretti, M. "The Current State of Capstone Design Pedagogy," Proceedings of the American Society for Engineering Education Conference, June 2010.

4. Howe, S. "Focused Follow-up to 2005 National Survey," Proceedings of the American Society for Engineering Education Conference, June 2008.

5. Howe, S., Lasser, R., Su, K., and Pedicini, S. "Content In Capstone Design Courses: Pilot Survey Results From Faculty, Students, and Industry," Proceedings of the American Society for Engineering Education Conference, June 2009.

6. Dixon, G. "Experiencing Capstone Design Problem Statements," Proceedings of the American Society for Engineering Education Conference, June 2012.

7. Dixon, G. "Technical Design Reviews in Capstone," Proceedings of the American Society for Engineering Education Conference, June 2014.

8. Silverstein, D., Bullard, L., Seider, W., and Vigeant, M. "How We Teach: Capstone Design," Proceedings of the American Society for Engineering Education Conference, June 2013.

9. Rao, M., Hayes, C., and Lynch, K. "Survey Of Mechanical Engineering Capstone Design Courses Summary of Results," ASME International Mechanical Engineering Education Leadership Summit: ME Department Heads/Chairs Executive Committee Meeting, March 2015.

10. Howe, S., Rosenbauer, L., and Poulos, S. "2015 Capstone Design Survey - Initial Results," Proceedings of the 2016 Capstone Design Conference, June 2016.

11. Corbin, J. and Strauss, A. Basics of Qualitative Research: Techniques and Procedures for Developing Grounded Theory, Sage Publications, Third Edition, 2008. 